\title{
Marine Litter: Composition in Eastern Aegean Coasts
}

\author{
Hasan Cerim ${ }^{1}$, Halit Filiz², Anil Gülşahin'1, Mustafa Erdem ${ }^{1}$ \\ ${ }^{1}$ Department of Fisheries and Seafood Processing Technology, Faculty of Fisheries, Muğla Sıtkı Koçman \\ University, Muğla, Turkey \\ ${ }^{2}$ Department of Hydrobiology, Faculty of Fisheries, Muğla Sıtkı Koçman University, Muğla, Turkey \\ Email: ${ }^{\text {hasancerim@gmail.com }}$
}

Received 17 April 2014; revised 20 May 2014; accepted 23 June 2014

Copyright (C) 2014 by authors and OALib.

This work is licensed under the Creative Commons Attribution International License (CC BY).

http://creativecommons.org/licenses/by/4.0/

(c) (i) Open Access

\begin{abstract}
In this study, 28 trawl operations were carried out from four different bays (Gulf of Kuşadası, Gulf of Güllük, Gulf of Gökova and Marmaris) in eastern Aegean Sea between December 2008 and March 2011. Sampled litters were separated by materials: glass, plastic, metal, wooden and others. Totally, as percentage, plastic material comprises the biggest group (48\%) and it is followed by metal $(25 \%)$, glass $(12 \%)$, others $(12 \%)$ and wooden $(3 \%)$. Also regional litter densities were calculated for regions as $1692.0 \mathrm{item} / \mathrm{km}^{2}$ for Marmaris, $796.0 \mathrm{item} / \mathrm{km}^{2}$ for Gulf of Güllük, 175.0 item $/ \mathbf{k m}^{2}$ for Gulf of Kuşadası, and 58.0 item $/ \mathbf{k m}^{2}$ for Gulf of Gökova.
\end{abstract}

\section{Keywords}

Marine Pollution, Aegean Sea, Gulf of Kuşadası, Gulf of Güllük, Gulf of Gökova, Marmaris

Subject Areas: Environmental Sciences, Hydrology

\section{Introduction}

Ocean litter-also commonly referred to as "marine debris"-is a persistent and growing worldwide problem [1]. "Marine litter" is described by [2] as: "items that have been made or used by people and deliberately discarded or unintentionally lost into the sea and on beaches including such materials transported into the marine environment from land by rivers, draining or sewage systems or winds”. Marine habitats are contaminated with man-made items of litter from the poles to the equator and from shorelines, estuaries and the sea surface to the depths of the ocean [3]. Contingent on their sources and driving forces, waste materials may be distributed in large distances and depths at sea [4].

Marine litter dispersion and deposition are strongly influenced by ocean currents, tidal cycles, regional-scale

${ }^{*}$ Corresponding author. 
topography, including sea-bed topography and wind [5]. The very slow rate of degradation of most marine litter items, mainly plastics, together with the continuously growing quantity of the litter and debris disposed, is leading to a gradual increase in marine litter found at sea and on the shores [6]. Many of these items are highly buoyant, allowing them to be carried in currents for thousands of miles, endangering sensitive marine ecosystems and wildlife along the way [7]. Litter in the sea affects marine fauna through entanglement, or ingestion of such materials by animals [8]. The accumulation of such debris can inhibit the gas exchange between the overlying waters and the pore waters of the sediments, and the resulting hypoxia or anoxia in the benthos can interfere with the normal ecosystem functioning, and alter the make-up of life on the sea floor [9].

Marine litter threatens oceans and coasts, marine life, economy, safe navigation, and human health and safety [10]. Such litter can be harmful to wildlife and to human health [1] [11], medical and sanitary waste, and pieces of broken glass or metal, constitute a health hazard and can seriously injure people, directly or indirectly, discarded fishing nets can be a safety risk to boaters and divers [12], it has the potential to transport organic and inorganic contaminants [13] [14], can present a hazard to shipping and can be aesthetically detrimental [15]. Ghost fishing by loss of fishing gears causes economic losses [16] and cleaning of fishing gear from litters that causes time spent on fishing activities [17]. Ocean litter has been shown to affect at least 267 species worldwide, including sea turtles, seabirds and marine mammals [18].

Eastern Aegean coasts have been used by Greece and Turkey since the beginning of time. Coastal range between Greece Islands and Turkish coasts is not wide in many places. For example, the distance between Samos Island and Gulf of Kuşadası is only $1.58 \mathrm{~km}$. Many activities such as industrial shipping, fishing, and yachting are made in this coastal area. Due to intensive use of the area, coast pollution observed frequently, and seabed is occupied by litters come from both countries.

This study aims to learn the composition of marine litter found on the seabed of Eastern Aegean coasts and determine the litter sources and to find a way of conservation and prevention methods for natural life and human benefits. This is the first attempt to present the marine litter in eastern Aegean coasts of Turkey.

\section{Material and Method}

\subsection{Study Locations}

Trawl operations has been done in Marmaris, Gulf of Gökova, Gulf of Güllük and Kuşadası (Figure 1). Selected study locations are also four important tourism regions for Turkey. Especially in summer times, lots of foreign and native tourists go for holiday to these regions (It means that increasing of tourism traffic) and they make a pressure on these cities and their vicinities for 5 months. So we decided to work in these highly "under pressure" tourism regions.

\subsection{Sampling and Method}

Study was done in legal and prohibited areas for fishing activities. Trawling method which had been used by previous studies was considered the most suitable method for sampling [19]-[21]. From December of 2008 to March of 2011, 28 trawl operations were done in Gulf of Kuşadas1, Gulf of Güllük, Gulf of Gökova and Marmaris. Trawl ship is $26 \mathrm{~m}$ long and demersal trawling vessel. The trawl net which was used in study was a "Mediterranean Type Traditional Trawl Net”. One trawl operation was taking 2 hours with speed of 2.5 knots. Trawl net horizontal mouth width was measured as 32 meters. Trawling area's depths change from 9 to 210 meters. All litters was separated by materials as plastic, metal, wooden, glass and others, than counted for each hauls. Litter sources were estimated after materials were grouped.

\subsection{Data Analysis}

Litter densities, for each region, have been calculated with equation below [22]:

$$
\text { “ } D=n / A \text { ” }
$$

where " $D$ " is the density of litters per $\mathrm{km}^{2}$, " $n$ " is the number of litters collected and " $A$ " is trawled area $\left(\mathrm{km}^{2}\right)$.

\section{Results}

Totally, 806 waste materials were collected. Surface of the one trawled area has been calculated as $0.29632 \mathrm{~km}^{2}$. 


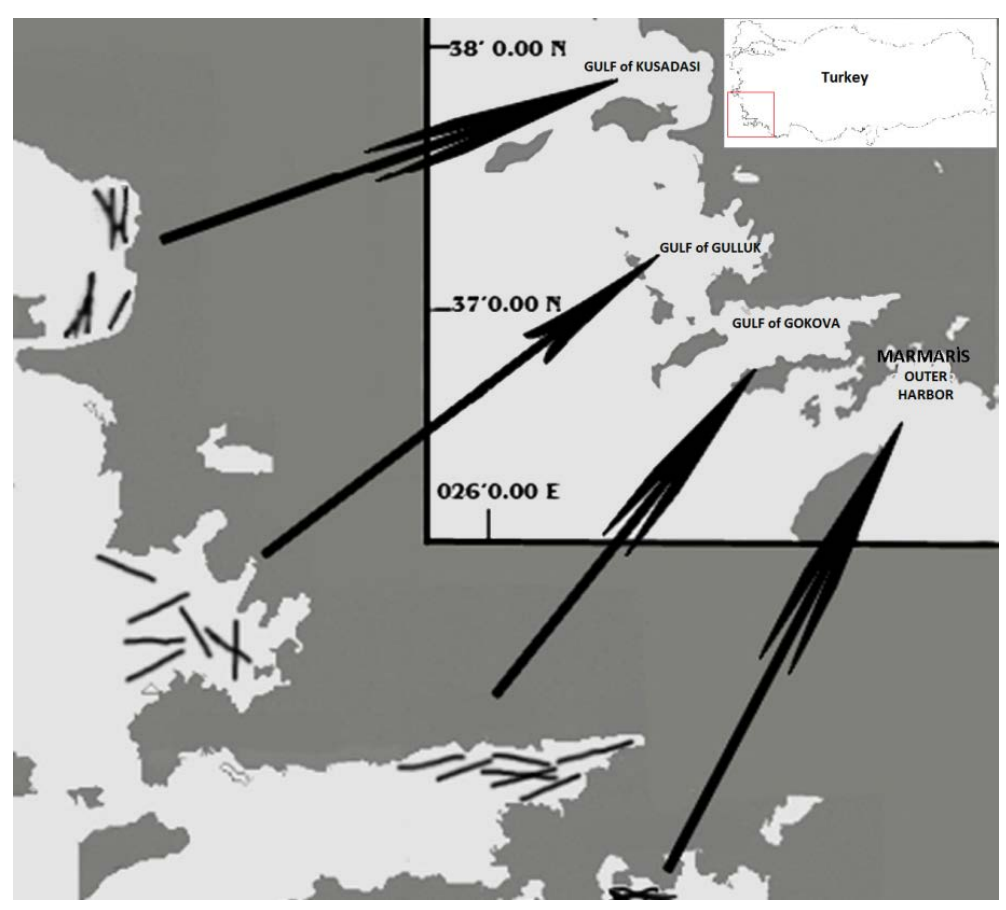

Figure 1. Study Area.

Litter concentrations were ranged between 58.0 and $1692.0 \mathrm{item} / \mathrm{km}^{2}$. Sources of litters were determined as domestic, fishing, recreational, yachting and rivers (Table 1).

Plastic material was found the highest value in all hauls as $47.89 \%$ (386 items) in total percentages. Plastic is followed by metal 25.19\% (203 items), glass $12.53 \%$ (101 items), and other materials by $11.54 \%$ (93 items) and wooden 2.85\% (23 items) (Figure 2).

Litter counts are shown in Table 2. Marmaris was found as the most polluted region $\left(1692.0 \mathrm{item} / \mathrm{km}^{2}\right)$, followed by Gulf of Güllük (796.0 item/ $\left./ \mathrm{km}^{2}\right)$, Gulf of Kuşadası (175.0 item/ $\mathrm{km}^{2}$ ) and Gulf of Gökova (58.0 item $/ \mathrm{km}^{2}$ ).

\section{Discussion}

\subsection{Litter Transfer, Accumulation and Effects}

Marine pollution, in recent years, impends and damages the natural life. Litters which transport easily to distant localities by local currents and global currents do not influence only one locality. In shallow coastal areas, the abundance of marine debris is generally much greater than on the continental shelf or on the deep seafloor, with the exception of some accumulation zones in the open sea [23]. Greater abundance of marine debris has been found in bays than in open coastal areas, which is a result of the influence of hydrodynamics [24] [25]. In bays, it is more difficult for litter disposed locally to be transported away from the point of disposal, due to weaker currents, and thus it is more likely to accumulate on the bottom. Furthermore, in open coasts, wave action may transfer a large portion of the marine debris from shallow areas to the shore [2].

Marine pollution leads to:

- Nanopolystyrene beads can inhibit photosynthesis and cause oxidative stress in algae [26].

- Marine debris can also cause habitat destruction by affecting water quality and causing physical damage to sensitive ecosystems. Coral reefs, sea grass beds and their bottom-dwelling species are very susceptible to the impacts of marine debris [27].

- Detent the selectivity with choking off access of meshes in fisheries and curling to fishing gears cause to losing time and fishing amounts when doing clearing processes [3].

- Marine mammal species entangle in and ingest many different types of debris, including derelict fishing gear and plastics [28]. 
Table 1. Materials: by groups, item varieties and litter sources.

\begin{tabular}{|c|c|c|}
\hline Groups & Items & Sources \\
\hline Metal & $\begin{array}{l}\text { Barrel, Anchor, Cans, Fridge, Fire extinguisher, Chains, Coasters, Chairs, } \\
\text { Guy (Steel Robes), Fishing hooks, Knives, Door handles, Tabor, } \\
\text { Frames, Bucket, Bicycle }\end{array}$ & $\begin{array}{c}\text { Fishing } \\
\text { Yachting } \\
\text { Domestic } \\
\text { By Rivers }\end{array}$ \\
\hline Glass & Bottles, Glass cases, Glass & $\begin{array}{l}\text { Yachting } \\
\text { Recreation }\end{array}$ \\
\hline Wooden & Logs, Twigs, Cabinets, Vessel Parts & $\begin{array}{l}\text { Domestic } \\
\text { Fishing } \\
\text { By Rivers }\end{array}$ \\
\hline Plastic & $\begin{array}{l}\text { Fender, Mug, Fishing line, Feeding bag, Bottle, Basket, Tent, Jack, Nylon, Buckle, } \\
\text { Seat sponge, Snorkel, Mask, Flippers, Sea-Beds, Canoe, Bag, Shoe, Rosary, CD’s, } \\
\text { Cable, Condom, Socks, Tires }\end{array}$ & $\begin{array}{c}\text { Domestic } \\
\text { Yachting } \\
\text { Recreation } \\
\text { By Rivers }\end{array}$ \\
\hline Others & $\begin{array}{l}\text { Fabric, Porcelain, Lamp Shade, Robe, Saddle, Swim-Wear, Fishing Nets, Tires, Papers, } \\
\text { Mobile Phones, Television, Radio, Books, Photograph Papers, Video Camera, Hats, } \\
\text { Heater, Kettle, Headphones, Clocks, Plaque, Purses, Socks (Wool) }\end{array}$ & $\begin{array}{l}\text { Domestic } \\
\text { Recreation } \\
\text { By Rivers }\end{array}$ \\
\hline
\end{tabular}

Table 2. Litter counts (per $1 \mathrm{~km}^{2}$ ).

\begin{tabular}{ccccc}
\hline Material (item $\left./ \mathrm{km}^{2}\right)$ & Gulf of Kuşadası & Gulf of Güllük & Gulf of Gökova & Marmaris Outer Harbor \\
\hline Glass & 17.0 & 10.0 & 0.00 & 34.0 \\
Plastic & 128.0 & 469.0 & 7.0 & 17.0 \\
Metal & 30.0 & 81.0 & 0.00 & 57.0 \\
Wooden & 0.0 & 226.0 & 58.0 & 88.0 \\
Other & 0.0 & 796.0 & 58.0 \\
Total & 175.0 & & 1692.0 \\
\hline
\end{tabular}

* One trawled area was calculated as $0.29632 \mathrm{~km}^{2}$ per operation.

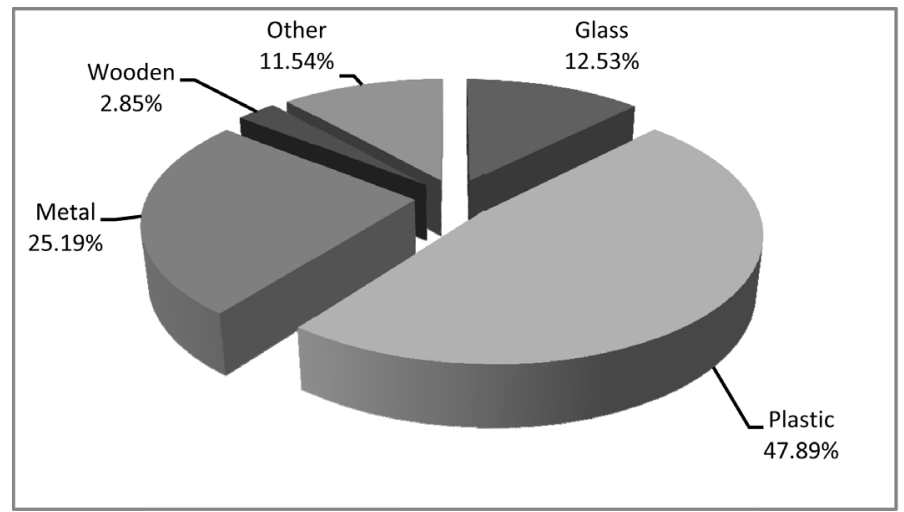

Figure 2. Distribution and percentage of litters.

- Lost fishing gear and gear parts are the most hazardous types of marine litter's pollution for marine life [29].

- Litter found in an off-shore fishing bank, has caused a serious economic loss to fishermen in fisheries [30].

- Marine debris washing ashore can be also be an aesthetic problem on beaches and may cause economic losses to tourism because it discourages swimming, boating and fishing activities [31].

\subsection{Reasons of Pollution in the Study Locations}

Plastic and synthetic materials are the most common types of marine debris [32] [22]. Almost every packaging and covering processes are done with plastic or other materials derived from it. 
In Turkey, despite presence of marine pollution prevention law [33], there is a serious situation emanates from absence of enough inspection mechanisms. Pollution from ships is clearly touched in [34]. Also Turkey has signed the protocol. Turkish seas have dense marine traffic such as fishing activities, container ships and daily tours especially during summer times. Without solid litters, also bilge water discharges contribute to pollution.

Regions which are studies carried out, are known by all over the world as very famous tourism regions. Besides, these regions are used excessively by shipping, yachting, daily tours, fish aquaculture systems and fishing activities. Without these factors, a few rivers and hotels discharge their waters to these regions.

South Aegean area is a favorite region for many indigenous and foreign tourists especially in summer times. So, population increases in coastal regions and makes pressure on seas. Besides, this region which includes some of the important Mediterranean harbors, does not only polluted by territorial litters but also it is polluted by blue tours, fishing and shipping activities.

Marmaris is known all over the world. There are so many hotels and inhabitants in this region. Especially in summer time, nearly 8.5 million tourists visit south-west of Turkey's coasts. Outer harbor is effected heavily from daily tours and yachting. Without this, also marine traffic has a big role in litter pressure on here. 2399 ships (Commercial and Personal ships) had come to only Marmaris region in 2010 [35]. In 1992 and 2007, there were two floods in Marmaris. For this reason, so many goods and other items (cans, plastic bottles, wooden etc.) passed to marine environment from territorial area (Table 2).

Gulf of Güllük is the biggest center of fish aquaculture systems in Turkey. There are too many fish aquaculture systems and hotels in this region. In addition to these factors, there is a big lagoon (Gulf of Güllük Lagoon) and fresh water source (Sarıçay River) in this gulf. Because of these situations, a great pressure exists on Gulf of Güllük. Except "plastic” material group, "other" material group litter numbers have considerable counts in this region. Fish aquaculture systems' wastes (Especially feeding bags, robes, and plastic materials), fishing activities (Trawling, loglines, longnets etc.), currents, and submerged illegal (refugee) boats had made it variable and high amounts (Purses, pants, fabrics, photograph papers etc.) (Table 2).

Gulf of Kuşadası is one of the biggest harbors in Mediterranean area. City reclines along with the coast. Great touristic passenger ships, fishing activities (Longline, trawling, purse-seining etc.) and domestic litters are sources of marine litters of Gulf of Kuşadası. During the sampling, especially, fishing and domestic plastic litters (plastic spoon, forks, bottles, plates etc.) have been found higher than other groups (Table 2).

Gulf of Gökova has the lowest litter density compared with the other areas. Because, daily tour ship owners are very sensitive, there is no broadly fishing activity and too much residential area and gulf is a close area towards most winds. So terrestrial litter transfer is weaker than the other regions by winds (Table 2).

Some of previous studies which have been done in Mediterranean, Aegean Sea and Turkish coasts of Black Sea are shown on Table 3.

\subsection{Outputs and Suggestions}

Most of countries and associations (USA, Australia, UK, Korea, EU, etc.) make studies on for prevent marine pollution [6]. Marine pollution studies in Turkey are insufficient for making decision in management.

In accordance with the study, for the lowest marine pollution or completely removing:

- Increasing natural awareness.

- Local and national briefing about dimensions of pollution in seas.

- Increasing inspections and applying sanctions.

- Working with universities for orientated work on decreasing existent of pollution.

- Instead of widely used plastic material, necessitate to using easy recycling material.

Table 3. Previous studies.

\begin{tabular}{cccc}
\hline Material (\%) & Eastern Mediterranean [25] & Western part of The Turkish Black Sea [21] & This Study \\
\hline Glass & 2.09 & 0.8 & 12.53 \\
Plastic & 60.6 & 92.5 & 47.89 \\
Metal & 25.73 & 2.1 & 25.19 \\
Wooden & - & 1.7 & 2.85 \\
Other & 11.55 & 6.6 & 11.54 \\
\hline
\end{tabular}


- Especially, working with bottom hauling gears owner's, consciousness of marine pollution was raised and told them to dump the litter taken out from sea bottom by hauling gear not back at the sea but to the land.

- Taking precautions for drifted territorial litter source with river currents and sewers before reaching to marine environment.

- Recycling centers should not be built near coasts and their numbers should be increased.

Monitoring of marine pollution is an advantage for decreasing environmental and socioeconomic damages. So management plans can be made easily according to polluted regions. Raising awareness on preventing marine pollution should be the main subject of studies.

World seas and oceans are not only considered with their offers also we have to respect them as habitat of living organisms.

\section{Acknowledgements}

Thanks for obtaining materials during the sampling period, typing and statistical analyzing processes to Sercan YAPICI, Özde ÖZKAN and Uğur KARAKUŞ and valuable shipmasters and crews of AKYARLAR, ÖMER EFE and DEVLET-3 trawl ships.

\section{References}

[1] Derraik, J.G.B. (2002) The Pollution of the Marine Environment by Plastic Debris: A Review. Marine Pollution Bulletin, 44, 842-852. http://dx.doi.org/10.1016/S0025-326X(02)00220-5

[2] Galgani, F., Fleet, D., Van Franeker, J., Katsanevakis, S., Maes, T., Mouat, J., Oosterbaan, L., Poitou, I., Hanke, G., Thompson, R., Amato, E., Birkun, A. and Janssen, C. (2010) Marine Strategy Framework Directive Task Group Report 10 on Marine Litter.

[3] Thompson, R., La Belle, B.E., Bouwman, H. and Neretin, L. (2011) Marine Debris: Defining a Global Environmental Challenge. GEF Council Meeting, 24-26 May 2011, Washington DC, 28 p.

[4] Schrey, E. and Vauk, G.J.M. (1987) Records of Entangled Gannets (Sula bassana) at Helgoland, German Bight. Marine Pollution Bulletin, 18, 350-352. http://dx.doi.org/10.1016/S0025-326X(87)80024-3

[5] Jeftic, L., Sheavly, S. and Adler, E. (2009) Marine Litter: A Global Challenge. UNEP Marine Litter Publications, 232 p.

[6] UNEP (2005) Marine Litter, an Analytical Overview. UNEP Marine Litter Publications.

[7] UNEP (2007) National Marine Debris Monitoring Program. UNEP Marine Litter Publications.

[8] Tonay, A.M., Dede, A., Öztürk, A.A. and Öztürk, B. (2007) Stomach Content of Harbor Porpoises (Phocoena phocoena) from the Turkish Western Black Sea in Spring and Early Summer. Rapp. Comm. int. Mer. Medit., 38, 616.

[9] Goldberg, E.D. (1994) Diamonds and plastics are forever? Marine Pollution Bulletin, 28, 466. http://dx.doi.org/10.1016/0025-326X(94)90511-8

[10] NOAA (2011) NOAA Marine Debris Program. http://marinedebris.noaa.gov/welcome.html

[11] Gregory, M.R. (2009) Environmental Implications of Plastic Debris in Marine Settings Entanglement, Ingestion, Smothering, Hangers-On, Hitch-Hiking, and Alien Invasions. Philosophical Transactions of the Royal Society B, 364, 2013-2026. http://dx.doi.org/10.1098/rstb.2008.0265

[12] UNEP (2001) Marine Litter — “Trash That Kills” brochure. UNEP Marine Litter Publications.

[13] Mato, Y., Isobe, T., Takada, H., Kanehiro, H., Ohtake, C. and Kaminuma, T. (2001) Plastic Resin Pellets as a Transport Medium for Toxic Chemicals in the Marine Environment. Environmental Science and Technology, 35, 318-324. http://dx.doi.org/10.1021/es0010498

[14] Teuten, E.L., Saquing, J.M., Knappe, D.R.U., Barlaz, M.A., Jonsson, S., Björn, A., Rowland, S.J., Thompson, R.C., Galloway, T.S., Yamashita, R., Ochi, D., Watanuki, Y., Moore, C., Viet, P., Tana, T.S., Prudente, M., Boonyatumanond, R., Zakaria, M.P., Akkhavong, K., Ogata, Y., Hirai, H., Iwasa, S., Mizukawa, K., Hagino, Y., Imamura, A., Saha, M. and Takada, S. (2009) Transport and Release of Chemicals from Plastics to the Environment and to Wildlife. Philosophical Transactions of the Royal Society B, 364, 2027-2045. http://dx.doi.org/10.1098/rstb.2008.0284

[15] Mouat, T., Lopez-Lozano, R. and Bateson, H. (2010) Economic Impacts of Marine Litter. KIMO (Kommunenes Internasjonale Miljøorganisasjon), $117 \mathrm{p}$.

[16] Moore, C.J. (2008) Synthetic Polymers in the Marine Environment: A Rapidly Increasing, Long-Term Threat. Environmental Research, 108, 131-139. http://dx.doi.org/10.1016/j.envres.2008.07.025

[17] KIMO (2010) Incident Highlights the Real Cost of Marine Litter. September 2010.

[18] California Ocean Protection Council (OPC) (2008) An Implementation Strategy for the California Ocean Protection 
Council Resolution to Reduce and Prevent Ocean Litter. 28 p.

[19] Kang, C.G. (2003) Marine Litter in the Republic of Korea NOWPAP MER/RAC.

[20] Koutsodendris, A., Papatheodorou, G., Kougiourouki, O. and Georgiadis, M. (2007) Benthic Marine Litter in Four Gulfs in Greece, Eastern Mediterranean; Abundance, Composition and Source Identification. Estuarine, Coastal and Shelf Science, 77, 501-512. http://dx.doi.org/10.1016/j.ecss.2007.10.011

[21] Topçu, N.E. and Öztürk, B. (2010) Abundance and Composition of Solid Waste Materials on the Western Part of the Turkish Black Sea Seabed, Aquatic Ecosystem Health and Management, 13, 301-306. http://dx.doi.org/10.1080/14634988.2010.503684

[22] Zhou, P., Huang, C., Fang, H., Cai, W., Li, D., Li, X. and Yu, H. (2011) The Abundance, Composition and Sources of Marine Debris in Coastal Seawaters or Beaches around the Northern South China Sea (China). Marine Pollution Bulletin, 62, 1998-2007.

[23] Katsanevakis, S. (2008) Marine Debris, a Growing Problem: Sources, Distribution, Composition, and Impacts. In: ofer, T.N., Ed., Marine Pollution: New Research, Nova Science Publishers, New York, 53-100.

[24] Hess, N., Ribic, C. and Vining, Y. (1999) Benthic Marine Debris, with an Emphasis on Fishery-Related Items, Surrounding Kodiak Island, Alaska, 1994-1996. Marine Pollution Bulletin, 38, 885-890. http://dx.doi.org/10.1016/S0025-326X(99)00087-9

[25] Katsanevakis, S. and Katsarou, A. (2004) Influences on the Distribution of Marine Debris on the Seafloor of Shallow Coastal Areas in Greece (Eastern Mediterranean). Water, Air, and Soil Pollution, 159, 325-337. http://dx.doi.org/10.1023/B:WATE.0000049183.17150.df

[26] Bhattacharya, P., Lin, S., Turner, J.P. and Ke, P.C. (2010) Physical Adsorption of Harged Plastic Nanoparticles Affects Algal Photosynthesis. Journal of Physical Chemistry C, 114, 16556-16561. http://dx.doi.org/10.1021/jp1054759

[27] Sheavly, S.B. (2007) National Marine Debris Monitoring Program: Final Program Report, Data Analysis and Summary. Prepared for U.S. Environmental Protection Agency by Ocean Conservancy, Grant Number X83053401-02, 76 p.

[28] Spruill, V. and Cousteau, P. (2010) Trash Travels. International Coastal Cleanup 25th Anniversary 2010 Report. Ocean Conservancy.

[29] Laist, D.W. (1996) Marine Debris Entanglement and Ghost Fishing: A Cryptic and Significant Type of Bycatch? Proceeding of Solving Bycatch: Considerations for Today and Tomorrow, 25-27 September 1995, Seattle, 33-39.

[30] Williams, A.T., Simmons, S.L. and Fricker, A. (1993) Off-Shore Sinks of Marine Litter: A New Problem. Marine Pollution Bulletin, 26, 404-405. http://dx.doi.org/10.1016/0025-326X(93)90192-M

[31] Sheavly, S.B. (2005) Sixth Meeting of the UN Open-Ended Informal Consultative Processes on Oceans and the Law of the Sea. Marine Debris-An Overview of a Critical Issue for Our Oceans. 6-10 June 2005.

[32] Allsopp, M., Walters, A., Santillo, D. and Johnston, P. (2006) Plastic Debris in the World’s Oceans. Greenpeace, Amsterdam.

[33] Turkish Cabinet (1983) Environment Law. Law Number: 2872, Vol. 22, 499.

[34] MARPOL (1978) 1978 International Convention for the Prevention of Pollution from Ships, 1973 as Modified by the Protocol of 1978 (MARPOL 73/78).

[35] Turkey Tourism Agency Statistics (2010) http://sgb.kulturturizm.gov.tr/belge/1-90750/turizm-istatistikleri.html 